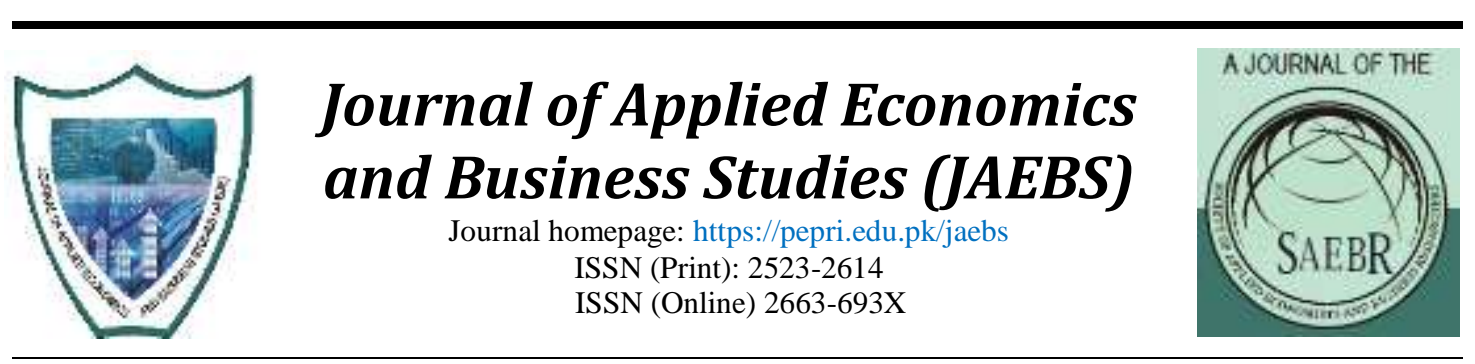

\title{
How Election Process is Rent-Seeking in Pakistan? A Case Study of Local Bodies Election in District Pakpattan
}

\author{
Anwar Shah ${ }^{1}$, Nasrullah Habib ${ }^{2}$ and Muhammad Zeeshan Younas ${ }^{3 *}$
}

${ }^{1}$ Associate Professor, School of Economics, Quaid-e-Azam University Islamabad.

${ }^{2}$ M.Phil. Graduate, School of Economics, Quaid-I-Azam University Islamabad.

${ }^{3} \mathrm{Ph}$.D. Scholar, School of Economics, Quaid-I-Azam University Islamabad.

\begin{abstract}
This study examines the difference between the total spending on the election campaign in 54 Union councils during local bodies' election and the expected developmental fund for the same area. The study is based on primary data collected from 324 contesting candidates for the chairmanship/vice-chairmanship of 54 union councils (UCs) in district Pakpattan during the local bodies' election of 2015 in Punjab, Pakistan. Per local bodies council rules, a winning chairman of UC has to allocate developmental funds in the area. So, the whole process of local bodies' election is for the finalization of a person among the people, who could be given the mandate to use the developmental funds. In this regard, we assume that the prevailing process of election is rent-seeking for society, in the sense that the total cost of the election process for society is greater than the developmental funds for which the same process is conducted. Candidates consume more than the allowed limit set by the Election Commission of Pakistan (ECP). Hence, society bears the monetary cost of spending more than the set limit and non-monetary costs like rivalry, foes, conflicts, etc. The analysis of data shows that the total amount of campaign spending is 473.27 million rupees which are significantly more than the allowed limit, set by ECP as well as the total allocated developmental funds (128 million) of 54 union councils. The study shows that the whole process of local bodies' election is putting rent of 345 million on society. Apart from monetary cost, this process brings those people to the power corridors who themselves break ECP rules. The study suggests comprehensive reforms in the process of the election campaign for saving society from its associated cost.
\end{abstract}

Keywords

Election

Campaign,

Political

Process, Local

Bodies'

Election,

Rent-Seeking

JEL

Classification C24, I21, I24

mzeeshan@eco.qau.edu.pk 
Anwar Shah, Nasrullah Habib and Muhammad Zeeshan Younas

\section{Introduction}

We know that market failure rationalizes the intervention and role of a government in the allocation of resources in an economy (Buchanan, 1968; Menon \& Yao, 2017; Sun et al., 2020). In this regard, the debate regarding the process of formation of the government has converged on democracy (Downs, 1995; Sagar, 2019). In a democratic society, every adult, on average, is entitled to contest the election and become part of the government. Likewise, every adult has the opportunity to elect people, whom they wish and consider eligible for running the affairs of government. To let people, whom they should choose for running the affairs of government, the candidates are provided an opportunity to inform the general people, before the election, about the program they wish to implement after having the reign of government. Such dissemination of information is done through the election campaign. Hence, the process of the election campaign is an integral part of the formation of government in a democracy at all three tiers of government, that is, federal, provincial, and local (Saward, 2008).

The efficiency of the process of election campaign requires that the associated cost must not exceed the return that the ensuing government is supposed to provide to society. In other words, the net returns of the process of election must not be negative. Moreover, the private cost of each contesting candidate on an election campaign must not exceed the allowed limit for the same purpose set by constitutional bodies such as the election commission of Pakistan (ECP). In case this is not followed by the letter and spirit, then one can claim that the process of election campaign involves rent-seeking. ${ }^{1}$ In this paper, we are interested to examine whether the process of the election campaign is rent-seeking. We take local bodies' election as a testbed for examining the answer to our question. We examine the amount of rent conferred on the society due to the process of the election campaign in local bodies election of 2015 held in district Pakkpattn, Punjab Pakistan.

What is rent-seeking? According to Lambsdorff (2002), rent-seeking involves transfer costs. That is the rent-seeking activity is for transferring the fixed rent and such activities do not increase the size of the prize. Hence, in an effort to get the prize, if the cost of effort for transferring the prize gets bigger and larger, then, society falls to a disadvantaged position. Lambsdorff (2002) is of the view that this transfer cost of resources is rent dissipating. Tullock (1967) has explained such rent-seeking in terms of the administrative cost of transferring tax and tariffs revenue to state account from people account. Such administrative cost includes salaries of tax inspectors and customs officials as well as public costs for containing smuggling and tax evasion. Such costs lower welfare and is a sort of deadweight loss and waste. They are not aimed at increasing production or lowering costs to maximize profit. Tullock (1975) considers the effort for obtaining subsidies a pure waste that neither raises production nor bears

${ }^{1}$ The literature covers such discussion in the context of rent seeking. See, for example, Tullock (1967), Krueger (1974), Posner (1975) and Dougan, (1991).

98 
any other fruit for third parties. Tullock (1975) is of the view that: "The transfer itself may be cost less, but the prospect of the transfer leads individuals and groups to invest resources in either attempting to obtain a transfer or to resist a transfer away from themselves. P-109"

Based on the above discussion we consider the money spent on the election campaign a transfer cost for having some fixed developmental funds. To our knowledge, the literature on election campaigns mostly discusses the relationship between campaigning cost and votes gained (see, for example, Ansolabehere \& Snyder, 1996; Goldstein \& Freedman, 2000). In addition, we find literature related to political contests for rents and transfer (Hillman \& Riley, 1989; Fu \& Wu, 2019). However, there is a lack of empirical analysis related to how political contest through the process of election campaigning becomes a transfer cost for the allocation of developmental funds. This paper aims to fill this gap by examining the transfer cost of developmental funds from the government exchequer to the doorsteps of common people in the 54 Union council of district Pakpattan.

We collect primary data from 324 candidates, who contested election for the seat of chairmanship/vice chairmanship of union council in district Pakpattan in the local bodies' election of 2015 in the province of Punjab, Pakistan. The data is still valid as till today no new local election has been held. It is pertinent to mention that there are 54 union councils in district Pakpattan. Per rules of the Election Commission of Pakistan (F.4 (10)/2015-LGE (P)) a candidate for chairmanship/vice-chairman can spend up to PKR 100,000 (One hundred thousand) in the election campaign. ${ }^{2}$

Per rationality, the transfer cost of the developmental fund will be low if candidates avoid deviation in spending and follow the rules of ECP. However, spending on election campaigns is like N-players prisoner dilemma game. Each candidate in the election is like a player in this game. In case, each player sticks to the limit set by ECP, then transfer cost will be low and we will have a socially optimal solution. However, each player has an incentive for deviation from the rules of ECP if they think that doing so can attract more votes and increase their probability of a win. If every player plays the dominant strategy, Nash equilibrium will be sub-optimal, thus putting a huge cost on society. Based on this theory we expect a significant amount of rent-seeking activity, thus enhancing transfer cost, in the process of election campaigning during local bodies' election of 2015 in Pakkpattn, held in Punjab, Pakistan.

The analysis of the collected data shows that on average every candidate for chairmanship/vice chairmanship of union council consume1.56 million Pakistani rupees

\footnotetext{
${ }^{2}$ The relevant clauses is 17 (d) per code of conduct of ECP for contesting local bodies election (F.4 (10)/2015-LGE (p) is: The contesting candidates of chairman and vice chairman of union council can spend 100000 rupees for election campaign.
} 
(PKR) on the election campaign. Some candidates spend more than PKR 5.2 million. Furthermore, the cost of each subhead is multiple times the limit set by ECP. The society as a whole bears the rent of PKR 345 Million for the expected developmental fund of PKR 32 Million per year (PKR 208 million for 4 years). It is worth mentioning that we do not take into account the campaigning cost other than chairmanship/vicechairmanship in a union council. In addition, we do not take into account the time and other non-material costs, when calculating this amount of rent.

The rest of the paper is organized as follows. Section 2 provides a brief review of the literature. Section 3 explains the structure of local government, election procedure and code of conduct. Section 4 describes the theoretical framework and explains the hypotheses of the study. Section 5 provides details about data collection. The details of the findings are provided in Section 6, while Section 7 concludes.

\section{Literature Review}

In the literature, we find studies examining the relationship between a candidate's campaign expenditures and his or her vote share in U.S. politics (e.g., Ansolabehere \& Snyder, 1997; Erickson \& Palfrey, 1996; Green \& Krasno, 1988; Jacobson, 1980, 1985, 1990). Likewise, we find literature on the same phenomenon for Britain (Pattie et al., 1995). The intuition behind these studies is that more spending ought to benefit the spender - that spending and vote share ought to be correlated; other things being equal (See also, Cox \& Thies, 2000). The empirical findings on the effects of election campaigning at the local level support the view that campaign spending by parties or candidates put an impact on votes gained (Green \& Krasno, 1988; Johnston \& Pattie, 1997; Pattie et al, 1995). Evidence for this comes from analysis both of single elections and of election series in Canada (Palda, 1973), the United States (Grier, 1989; Jacobson, 1980; 1985; Welch \& Hibbing, 1984), and Britain (Johnston et al, 1988; Pattie et al, 1995). In addition, we find studies that examine how rent-seeking behavior affect the political dynamics in African countries (Mbaku, 1994; Mbaku \& Kimenyi, 2015).

A series of papers have explained various aspects of rent and rent-seeking after Tullock (1967). For example, Nitzan (1994) provides a review of models explaining the behavior of rent-seeking agents. The paper provides how various work such as Baik \& Shogren (1992) model the rent-seeking process for risk-neutral agents having an equal probability of winning the rent. Other papers discuss how rent is modeled for the riskaverse agents (Hillman \& Katz, 1984) and the asymmetric valuation of the prize (Baye et al., 1992). Likewise, Nitzan (1991) shows that when the competition for winning a prize is between two groups instead of two individual rent-seekers, the amount of rent dissipation drops. This is due to a decline in the intensity of the level of competition and free-riding by some contenders in the group. Hillamn \& Riley (1989) develop a general model of politically contestable rents and transfers which includes asymmetric valuation for the prizes. In such cases, the outlays made in contesting a prize are substantially 
below the value of the prize. The reason is that asymmetric valuation acts as a barrier to entry and the number of agents actively contesting a politically allocated rent or transfer gets small.

Zupan (2015) discusses the supply side of the rent and examines how rulers, political leaders, and public employees can take advantage of their positions. The insiders in the government have the motive, political power, and opportunity of rent-seeking and hence are more likely to grab rent from people. For example, In China, 203 of the 1,271 richest people in the country (about one in seven) are delegates to the nation's Parliament or its advisory body. The delegates' combined net worth is nearly USD 500 billion. 18 of them have assets exceeding the combined wealth of all 535 members of the US Congress, ex-president Obama's cabinet, and all nine members of the Supreme Court. Officials in the government have imperfect accountability and no competition on the supply side, hence, they earn more rent.

Patnaik (2015) shows that firms and industries across the world regularly engage with political and government players to obtain economic rents through a variety of strategic tools. Rovinaruand (2014) show that, for years, the US and several EU countries have provided government support that was found to be against WTO rules to airplane manufacturers Boeing and Airbus, respectively. Even in modern democratic countries, the costs imposed by rent-seeking - both indirectly through welfare losses and directly through the costs rent-seekers have to expand to secure their rents (Luchsinger \& Mueller, 2003).

More related work with our papers is of Laband \& Sophocleus (1992). They examine the expenditures on non-exchange, non-charity transfer activity in the United States in 1985. By non-exchange transfer, the study implies that the gain in wealth by the recipient(s) comes at the expense of one or more individuals from whom the transfer is originated. That is, the transfer is involuntary from the perspective of one or more individuals whose wealth is targeted. Such non-exchange and non-charity transfer activity include, but is not limited to, theft and theft prevention, fraud, and governmentsponsored transfer programs. The study reports expenditure that is designed to facilitate and inhibit non-exchange transfers, executed privately or through the state. The numbers indicate that individuals plausibly invested nearly a trillion dollars in transfer activity that year. The nominal GNP of the USA in 1985 was just over $\$ 4$ trillion, which includes numerous transfer-related resource investments that arguably should be subtracted out. Transfer activity thus apparently constitutes a much larger fraction of all economic activity conducted in the United States than previously recognized. The study terms such expenditure as rent-seeking as here a person is investing in protecting the gains which they have already achieved through some sources.

We take help from the literature of rent-seeking and want to show empirically; that to what extent expenditure on election campaign in a local body election is a transfer cost of developmental funds from the government to people. Based on the findings, we 
Anwar Shah, Nasrullah Habib and Muhammad Zeeshan Younas

aim to show that each of the candidates is after some rents associated with a win (Frank \& Cook, 2013).

\section{The Structure of Local Government, Election Procedure and Code of Conduct}

According to Punjab local government act 2013, the local government has three tiers and consists of the district, tehsil, and union councils. ${ }^{3}$ The government at the level of union council has 13 members including the chairman and vice chairman as shown in Table 1. Chairman and vice chairman contest election on one symbol. Each union council is further divided into six wards. Each ward contains 2000 to 3000 registered votes. There are 6 general counselors in each union council. These 6 general counselors are elected from 6 wards of the union council. There are 2 lady councilors, 1 minority councilor, 1 labor councilor and 1 youth member in each union council. One of the lady councilors is elected from the first three wards, while the second lady councilor is elected from the remaining three wards. On the other hand, the constituency of the labor councilor, minority councilor and youth member consists of all 6 wards of the union council.

\section{Table 1: Composition of the candidate in a union council}

\begin{tabular}{|c|c|c|c|c|c|c|c|}
\hline Chairman & $\begin{array}{c}\text { Vice } \\
\text { chairman }\end{array}$ & $\begin{array}{c}\text { General } \\
\text { councilor }\end{array}$ & $\begin{array}{c}\text { Lady } \\
\text { councilor }\end{array}$ & $\begin{array}{c}\text { Youth } \\
\text { councilor }\end{array}$ & $\begin{array}{c}\text { Minority } \\
\text { councilor }\end{array}$ & $\begin{array}{c}\text { Labor } \\
\text { councilor }\end{array}$ & Total \\
\hline 1 & 1 & 6 & 2 & 1 & 1 & 1 & 13 \\
\hline
\end{tabular}

The election commission of Pakistan (ECP) appoints "District Returning Officer" for every district and "Returning Officer (RO)" for every constituency. Per rules, ECP announces the schedule of an election. After the announcement people submit nomination papers for contesting an election. The nomination papers are checked by RO and announce decisions about its acceptance or rejection. An appeal against the acceptance or rejection of the nomination paper can be filed with the appellate tribunal, which makes the final decision. Next, the final list of the contesting candidates is prepared by RO and each is allocated election symbols according to party affiliation or per independent capacity of the candidate. After allotting of election symbol candidates start a formal campaign, which lasts till 48 hours before the day of the election. ECP provides copies of the voters' lists to RO, who divide these copies among presiding officers per polling station. A voter can cast vote after confirming his name in the voter list, while polling is continuing from 8.00 am to $5.00 \mathrm{pm}$, without any break. Finally, the presiding officer counts the casted votes in the presence of the candidate or the agents of the candidates and makes a statement in which the details of all the votes of candidates are given. This statement along with unused material is sent to RO. In addition, the presiding officers announce the results of the polling stations and give its copy to relevant contesting candidates. After receiving results from all polling stations,

${ }^{3}$ See for detail of the act http://punjablaws.gov.pk/laws/2542.html

102 
Journal of Applied Economics and Business Studies, Volume. 4, Issue 4 (2020) 97-116 https://doi.org/10.34260/jaebs.445

RO compiles the unofficial results and sends them to ECP on the prescribed form. The official results are announced by ECP.

\section{Theoretical Framework and Hypotheses}

We assume that a contestant candidate for chairmanship/vice-chairmanship is a rational economic agent (Sugden, 1991; Vriend, 1996). The objective of such an agent is to maximize private gains, which is winning the election. However, winning the election is not an end; rather it is a means to an end, which is to decide on the allocation of funds that are set aside in the annual budget of the Punjab government for each union council in a district. The dilemma is that making a decision about the allocation of funds for the developmental purpose of a union council is a social objective and the candidates are less likely to receive private rewards from this process. If other members of society receive benefits, he will also receive the same in the capacity of a member of the same society. Per economic theory a selfish person thinks about the private rewards, hence the maximization of the social objective cannot be the primary goal of a selfish person. In other words, every candidate must consider earning private rewards in the guise of promoting social objectives. Thus, each candidate expects to receive back some private returns from spending. All private returns are in the form of rents associated with a win (Frank \& Cook, 2013). Such rents included but not limited to, granting approval to benefit his/her near and kins, receiving a kickback from contractors, becoming influential in giving/selling jobs etc. (Krauger, 1974; Hillman \& Riley 1989)

According to Zuban (2015), government insiders capture rents as they face imperfect accountability. Financial rents can be secured through the diversion of public funds or from payments received from other sources (legal as well as illegal). The various potential channels for material remuneration include campaign contributions, honoraria, in-kind gifts, revolving-door positions in the industry, and payments to family members and family businesses. The rents may be derived from relevant interest groups in return for promoting particular policies. They also may accrue on account of politicians' threatening to undertake activities that will make an interest group worse off. In addition, Zuban (2015) shows that people in government have power, opportunity, and motive for involving in rent-seeking. The "motive" is symbolized by the level of election spending.

We do not capture the total value of rent in the current study. However, we use the amount of spending over and above the allowed limit as a proxy for rent. We assume that a person is more rent seeker if the amount he spends during an election campaign is higher than the allowed limit. He must be expecting to get a return for this money. In case, he is not entitled to the salary against chairman/vice-chairman, this means that the marginal productivity of his job for the society is worth zero. In case, he is entitled to a salary, then the marginal productivity is worth the amount of salary. Hence, we can say that the consumption beyond such amount of salary is rent on the society, which the society will bear but is less likely to receive any reward for the same. 
Based on the above discussion, we assume that the incentives associated with a win are likely to drag candidates to spend more on election campaigns than the set amount of ECP. The reason is that the election campaign process is like the N-players prisoner dilemma game. Every candidate should stick to the limit per set rules of ECP, however, every candidate has an incentive for deviation to consume more to attract more voters. Hence, hypothesis 1 of the study is:

Hypothesis 1: Every candidate is likely to deviate from the required standard of the allowed limit of the election campaign in order to earn the rent associated with a win.

In addition to the above, a candidate who belongs to the ruling party is more likely to consume more. The reason is that such candidates have the support of the ruling party. Hence, they know that after a win they can ask for extra funds and thus can reap more rents from kickbacks. Also, they can earn rent through various tactics such as giving jobs, releasing people from police custody, lodging and dislodging FIR with police, etc. Such candidates can easily realize people that he is indispensable for resolving their issues at the local and provincial level. Moreover, such candidates can go for returns against the law as they are less likely to face actions for such kind of actions from their opponents as the machinery of government is on average not cooperative with their opponents. The second hypothesis of the study, thus, is:

Hypothesis 2: A candidate affiliated with the incumbent ruling party in the province is likely to consume more as compared to other candidates

\section{Methodology and Data}

The secondary data on spending related to the election campaign by each candidate is not available. Hence, we designed a detailed questionnaire (see appendix A) and conduct a survey in "District Pakpattan", which is located about 210 kilometers away from Lahore, the capital city of Punjab. According to the 2017 census of Pakistan, the district Pakpattan had a population of 1.82 million of which about 16 percent lives in urban areas. Most of the people of Pakpattan belong to 200 different small and large clans. However, the dominant clans are Wattoo, Doger, Gujjar, Rajpoot, Jutt, Khagga, Bodla, Aryin, Sukhera, Hottiyana and Rath. Most of these clans have contested candidates at all tiers of an election. The main language in Pakpattan is Punjabi, which is spoken by 96 percent population. Agriculture is the main source of income for most of the population of Pakpattan.

The unit of analysis per questionnaire is a candidate who contested election for the post of chairmanship or vice-chairmanship in any of 54 union councils of district Pakpattan during local bodies' election held in 2015. ${ }^{4}$ Per ECP data 340 candidates contested election in 54 union councils of district Pakpattan. Out of these 340 candidates, we conducted interviews with 324 candidates. Out of 324 candidates, only

${ }^{4}$ It is to be noted that, we would have included fresh data, but new local election has not been held after 2015, till today 104 
4 candidates were interviewed through their kin, the rest of all candidates were interviewed in person directly. Our respondents include candidates from all mainstream political parties like Pakistan Muslim League Nawaz (PML-N), Pakistan Tehreek Insaff (PTI), Pakistan People Party (PPP), Jamat Islami (JI), Pakistan Awami Tahreek (PAT) and independent.

\section{Results}

We present results in various sub-section. In this regard, section 6.1 provides an overview of total campaigning cost. On the other hand, sections 6.2 and 6.3 compare campaigning costs across all Union Councils and position holders, respectively. The analysis of campaigning cost across Political Parties is given in section 6.4. The other related details are given in section 6.5

\subsection{An Overview of findings}

Table 6.1 summarizes the total cost of the election campaign in the Local Bodies Election of 2015 in district Pakpattan.

Table 6.1: An overview of total spending on election campaign

\begin{tabular}{|c|c|c|c|c|c|c|}
\hline $\begin{array}{c}\text { Nature of } \\
\text { constituency }\end{array}$ & $\begin{array}{c}\text { Number } \\
\text { of Seats }\end{array}$ & $\begin{array}{c}\text { Nature of } \\
\text { Candidature }\end{array}$ & $\begin{array}{c}\text { Number of } \\
\text { Candidates }\end{array}$ & $\begin{array}{c}\text { Respondent } \\
\text { Candidates }\end{array}$ & $\begin{array}{c}\text { Total } \\
\text { Campaigning } \\
\text { cost in } \\
\text { Millions }\end{array}$ & $\begin{array}{c}\text { Average } \\
\text { Campaigning } \\
\text { cost in Millions }\end{array}$ \\
\hline $\begin{array}{c}\text { Union } \\
\text { council }\end{array}$ & 54 & $\begin{array}{c}\text { Chairman } \\
\text { and vice } \\
\text { Chairman }\end{array}$ & 340 & 324 & 473.27 & 1.46 \\
\hline
\end{tabular}

Table 6.1 clearly shows that the contested candidates for chairmanship and Vicechairmanship in local bodies' election deviated from the prescribed rules of ECP regarding election spending. This deviation from the prescribed rules of ECP shows support in favor of our first hypothesis. Everyone in the election is better off if every candidate stays within the limit of ECP rules. However, the objective of winning an election incentivizes deviation from the socially optimal outcome.

It is pertinent to mention that the estimated budget for 54 union councils which contain 84 urban wards is 32 million rupees per our discussions with the relevant authorities in the local bodies office in district Pakpattan. Likewise, these union councils and municipal wards generate some revenues. This generated revenue is also used for developmental purposes. Nevertheless, the contested candidates of local bodies' election spent 473.27 Million rupees on the election campaign. This does not include the cost of the election campaign by candidates for councilors at wards levels. In other words, we have calculated the cost of a campaign for one seat of the union council, while there is a candidate who contests election for 12 other seats in a union council. 
This shows that to obtain authority for spending developmental funds of about128 million rupees, candidates for one seat only spend 473.27 million rupees. Hence, the whole process of election campaign add in transfer cost and show that candidates consume more so that to earn rents associated with a win.

We also examine whether election campaign spending varies across the union councils or not. Figure 6.1 depicts the average campaigning cost of candidates across union councils. It is evident from the figure, that rarely the average campaigning cost per candidate in a union council is less than a million rupees. The lowest and highest average campaigning cost ranges between 0.8 and 5.2 million rupees, respectively. The figure also shows that candidates of union council 11, 36 and 54 spent on average more amount than other UCs on the election campaign. Per our analysis and interviews, the main reason for this high expenditure is that candidates of these union councils are interested in contesting elections at a further higher level such as district government. Based on the above discussion, we can say that all candidates are players in this rentseeking process. They don't follow the defined rules regarding the election campaign spending set by ECP, thus hurting society negatively.

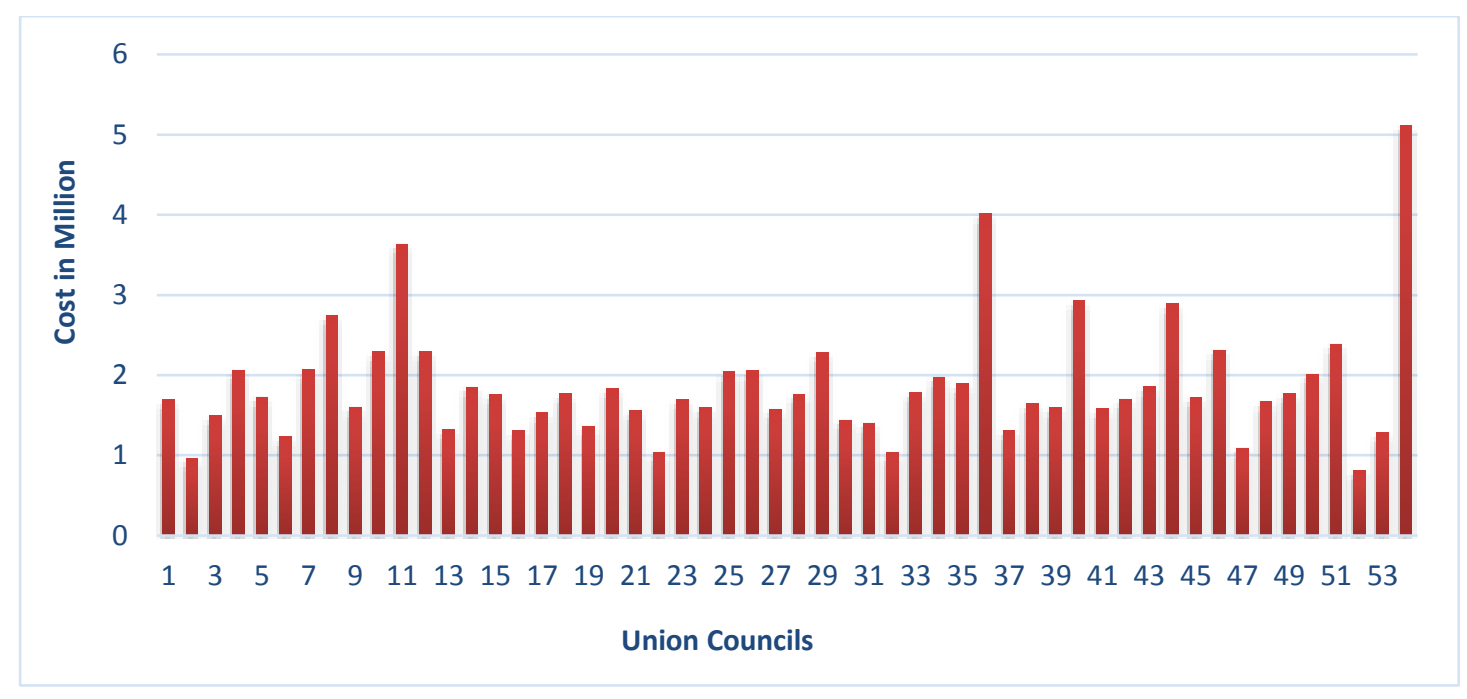

Figure 6.1: Average campaigning cost across union councils

\subsection{Campaigning Cost and Winning Position Across all UCs}

In order to examine whether the cost of campaigning plays any role in determining the position of a candidate in the list of winners, we present Figure 6.2. The figure compares the expenditure on campaigning across the first three positions holders in a union council. ${ }^{5}$ It is evident from the figure that the winner on average consumes more than the second and third position holders. The average expenditure of first position

${ }^{5}$ It is to be noted that in some union councils the context was held between two candidates. Hence, third bar does not exist for such union councils in the graph.

106 
holder is PKR 4.63 million while the average expenditure of second and third position holders is PKR 4.00 million and 1.48 million, respectively. The analysis shows that expenditure on campaigning does play a role in determining the position. This finding is in line with the early literature. We can say that the incentive for winning attracts candidates for deviation from socially optimal equilibrium, which is sticking to the rules of ECP.

However, the question is that what drags a candidate for consuming such a high level of expenditure for a seat of chairman/vice-chairman which does not carry any monetary incentive? There is no answer to this question other than that each candidate is after the rents associated with winning. The society bears a huge transfer cost for assigning the mandate of using the developmental fund.

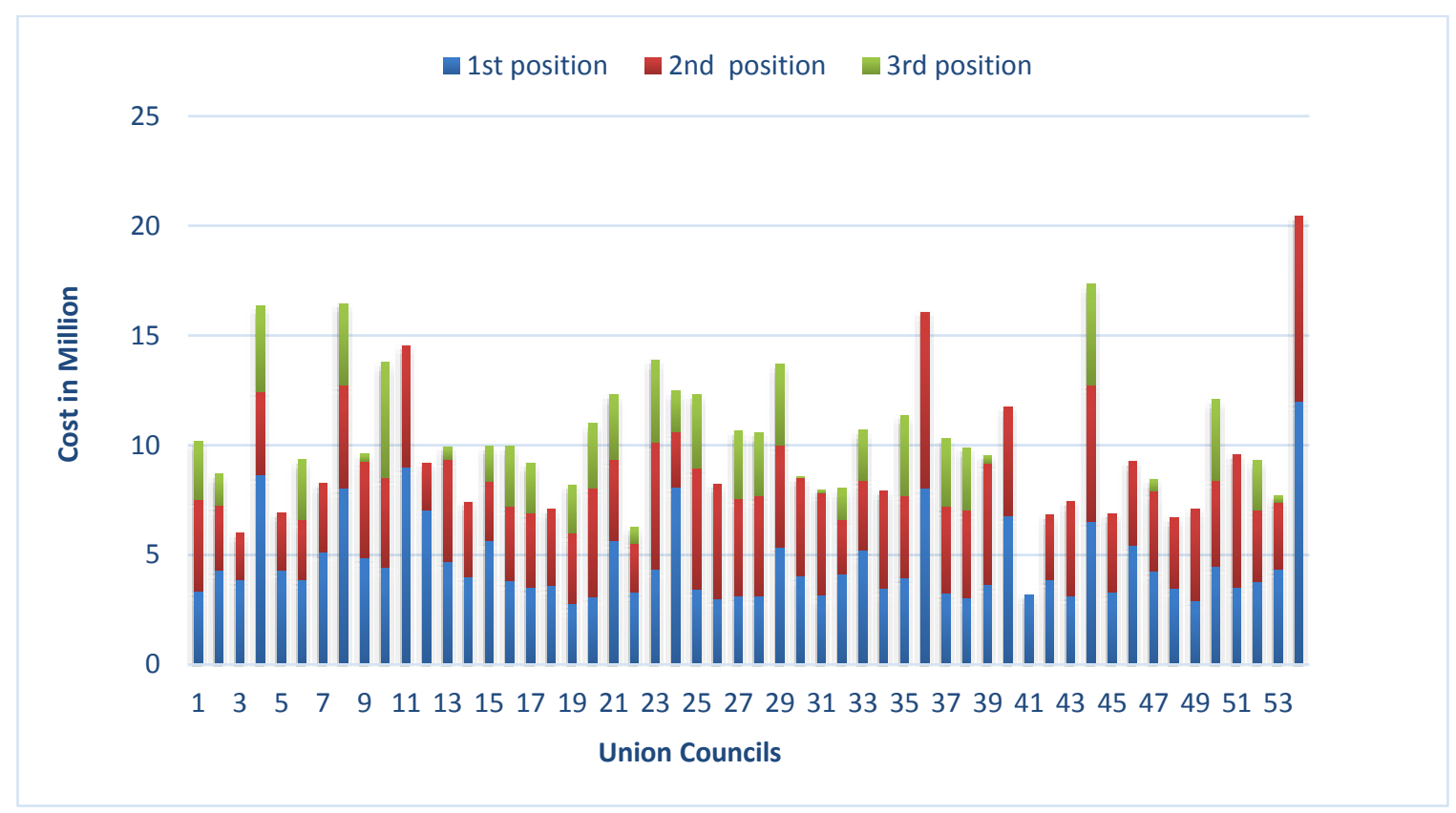

Figure 6.2: Campaigning cost across position holders of all union councils

\subsection{Campaigning Cost across candidates of various Political Parties}

Table 6.2 provides information about campaigning costs by candidates affiliated with various mainstream political parties. 
Anwar Shah, Nasrullah Habib and Muhammad Zeeshan Younas

Table 6.2: Campaigning cost across candidate affiliated with various political parties

\begin{tabular}{ccccc}
\hline Party Name & $\begin{array}{c}\text { Number of } \\
\text { Union } \\
\text { Council }\end{array}$ & $\begin{array}{c}\text { Total Number of } \\
\text { candidates }\end{array}$ & $\begin{array}{c}\text { Total } \\
\text { Expenditure } \\
\text { (In Million) }\end{array}$ & $\begin{array}{c}\text { Average } \\
\text { Expenditure } \\
\text { (In Million) }\end{array}$ \\
\hline PML(N) & 48 & 96 & 167.06 & 1.74 \\
Independent & 41 & 142 & 161.95 & 1.14 \\
PTI & 38 & 76 & 135.64 & 1.78 \\
PPP & 03 & 06 & 8.47 & 1.41 \\
PAT & 01 & 02 & 0.017 & 0.008 \\
JI & 01 & 02 & 0.13 & 0.66 \\
\hline Total & & 324 & 473.27 & 1.46 \\
\hline
\end{tabular}

The table shows that the average cost of the candidates of PTI is more than the average cost of the rest of the political parties which is not in line with hypothesis 2 . However, there is no significant difference across the mean expenditure of candidates from PML $(\mathrm{N})$ and PTI $(P=0.41)$. Hence, we can claim that data provide some support in favor of hypothesis 2 .

One can ask why candidates of PTI consume more than the candidates of PML (N). A possible answer is that the expenditure from the candidates of PTI is high as they have to compete with candidates from the ruling party of PML (N). Peer pressure from competing candidates could also force them for spending high on the election campaign. The closer the competition, the closer is likely to be the expenditure. This conjecture is also supported by Figure 6.3 which depicts the expenditure of the first three position holders across PML (N), PTI and independent. The figure indicates that on average the expenditure on campaigning by position holder is higher and close to the corresponding candidates on the same position. In the diagram, PPP shows a single bar as there were no candidates in the rank of second and third position holder from this party. Similar is the case of JI and PAT, whose candidates were not on the list of the first three positions.

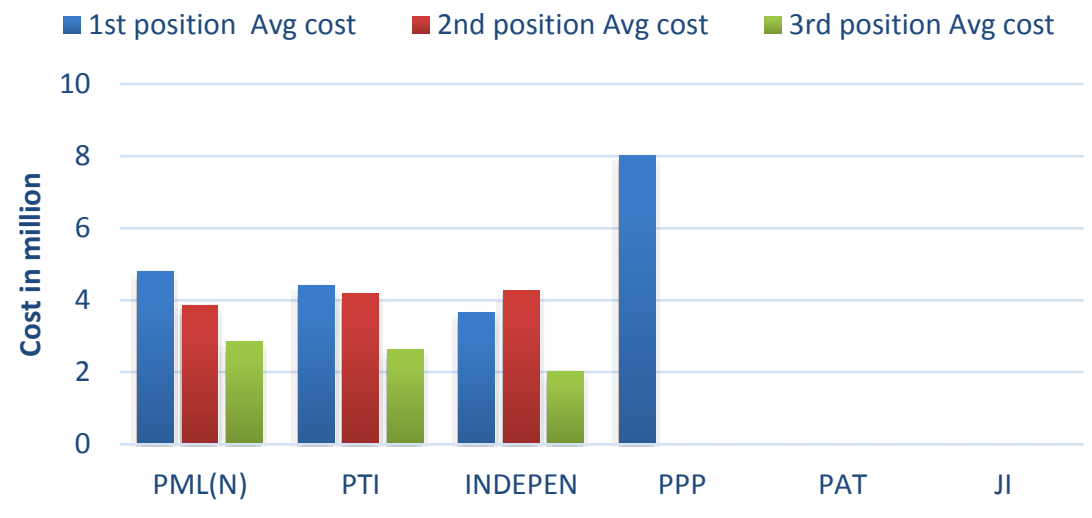

Figure 6.3: Average campaigning cost of candidates with respect to position across candidates affiliated with various political parties 
Table 6.3 provides details of the expenditure on the main three heads of an election campaign. The table helps us to know which category is costlier for the candidates. The table shows that candidates spent the highest amount on the provision of gifts and donations to voters. The second major head of election spending is an advertisement, while spending on the public meeting is the third major head for candidates. In nutshell, we can say that candidates on average consume more than the allowed limit on all main heads of the election campaign.

Table 6.3: Campaign cost across various heads

\begin{tabular}{lc}
\hline Category & Total Cost (Millions) \\
\hline Gifts and Donations & 171.40 \\
Advertisement & 121.78 \\
Transportation Cost & 99.20 \\
\hline
\end{tabular}

\section{Conclusion and Policy implication:}

The main objective of an election process in general and at the local level, in particular, is to assign power and funds related to the collective objectives of a society. In this regard, all individuals are the same; hence all can claim the right to political leadership. In order to decide who among the people be assigned the collective responsibility, almost all civilized societies of the world have adopted the process of one vote-one person. The societies that are following this process are called democratic societies. In a democratic society, every adult, on average, is entitled to contest an election and become part of the government. Likewise, every adult has the opportunity to elect people, whom they wish and consider eligible for running the affairs of government. To let people, whom they should choose for running the affairs of government, the candidates are provided an opportunity to inform the general people, before the election, about their program. Such dissemination of information is done through the election campaign. Hence, an election campaign is an integral part of the formation of government at all three tiers of government, that is, federal, provincial and local.

The efficiency of the process of election campaign requires that the associated cost must not exceed the return that the ensuing government is supposed to provide to society. If this is not the case, then the process of election campaign reflects a huge transfer cost and shows a rent-seeking activity on the part of candidates. This paper examines the transfer cost and rent-seeking aspect of the process of the election campaign in a local bodies' election at district Pakpattan, in the province of Punjab, Pakistan.

Rent-seeking is like the transfer costs of some funds or commodity. We find in the literature that transfer cost decrease welfare of the society as mentioned by Tullock (1967) that taxation and tariffs shift part of consumers' rent to the state but require administrative costs in the form of salaries for tax inspectors or customs officials. Such 
costs lower welfare and must be added to the Harberger triangle that is deadweight loss and is a form of waste. Based on the same example, an election campaign is like a transfer cost of some developmental funds from the government to the public. This is contrary to the transfer cost of taxation where funds come from the public to the government. To our knowledge, the currently available literature on election campaign examines the relationship between campaigning cost and votes gained (see for example, Ansolabehere \& Snyder, 1996; Erickson \& Palfrey, 1996) as well as election campaign and rent-seeking. This paper takes help from the available literature and empirically estimates the transfer cost and rent-seeking based on data of campaigning cost in 54 Union Councils of district Pakpattan. We collect data from 324 candidates, who contested election for the seat of chairmanship or vice-chairmanship in the 54 UCs of district Pakpattan.

Based on the referred literature, we assume that the campaigning cost for the transfer of developmental funds will be low if candidates avoid deviation in spending and follow the rules of ECP. However, the process of an election campaign is like an N-players prisoner dilemma game for the candidates. Each candidate is a player in the game. In case, each player sticks to the limit set by ECP, then campaigning cost will low, giving us a socially optimal solution. However, each player has an incentive for deviation as doing so can attract more votes. Hence, each player plays the dominant strategy, putting a huge cost on society. Based on this theory we expect a significant amount of rentseeking activity in the election campaigning during local bodies' election of 2015 in Pakpattan, held in Punjab, Pakistan.

Our data shows that on average a candidate for chairman/vice chairman in a union council consumes 1.56 million rupees on the election campaign. We also find that some candidate spends more than 5.2 million rupees. Furthermore, the cost of each subhead is multiple times the limit given by ECP. The society as a whole bears the transfer cost of PKR345 Million for the expected developmental fund of PKR 32 Million per year (128 million for 4 years). It is worth mentioning that we do not take into account the campaigning cost of the other 12 members of a union council as well as the time and other non-material costs while calculating this amount of transfer cost. In addition, the paper lack to quantify the rents, which each candidate is after. We do show that transfer cost is equal to election campaigning cost, which is like a rent-seeking cost, as it does not increase profit for the society. However, we could not show the exact amount of such prize or rent.

Our work offers grounds for reforms in the election process. First of all, the institution of ECP must show its presence with full strength, so that they can implement and impose their power related to the election campaign. Also, there should be support from all other institutions such as police, local administration with ECP in implementing their rules. Moreover, there is a need for serious discussion related to the cost associated with an election campaign at policy-making forums such as provincial and federal 
Journal of Applied Economics and Business Studies, Volume. 4, Issue 4 (2020) 97-116 https://doi.org/10.34260/jaebs.445

parliament. The current process of election and the election campaign is not only inefficient but put a huge monetary and non-monetary transfer cost on the society. Hence, the members of the parliament of Pakistan should seriously consider the transfer cost and renting aspect of an election campaign and come up with a substitute that is democratic as well as cost-efficient.

\section{References}

Ansolabehere, S., \& Snyder, J. M. (1997). The inter election dynamics of campaign finance: US House elections, 1980-94. In Legislative Studies Quarterly (Vol. 22, No. 1, Pp. 124-124). University Of Iowa, W307 Seashore Hall, Iowa City, Ia 52242-1409: Comparative Legislative Research Center.

Baik, K. H., \&Shogren, J. F. (1992). Strategic behavior in contests: comment. The American Economic Review, 82(1), 359-362.

Baye, M. R., Kovenock, D., \& De Vries, C. G. (1992). It takes two to tango: equilibria in a model of sales. Games and Economic Behavior, 4(4), 493-510.

Blankart, C. B., \& Ehmke, D. C. (2015).Overcoming the Rent-Seeking Defect in Regional Policy: Time to Re-think the Institutional Design. DICE Report, 13(3), 44.

Buchanan, J. M. (1968). The demand and supply of public goods (Vol. 5). Chicago: Rand McNally.

Cox, G. W., \&Thies, M. F. (2000). How Much Does Money Matter?"Buying” Votes in Japan, 1967-1990. Comparative Political Studies, 33(1), 37-57.

Dougan, W. R. (1991). The cost of rent seeking: is GNP negative?. Journal of Political Economy, 99(3), 660-664.

Downs, A. (1995). The Origins of an Economic Theory of Democracy Anthony Downs. Information, Participation, and Choice: An Economic Theory of Democracy in Perspective, 197-240.

Eagles, M. (1993). Money and votes in Canada: Campaign spending and parliamentary election outcomes, 1984 and 1988. Canadian Public Policy/Analyse de Politiques, 432-449.

Forrest, J., Johnston, R. J., \& Pattie, C. J. (1999). The effectiveness of constituency campaign spending in Australian state elections during times of electoral volatility: the New South

Frank, R. H., \& Cook, P. J. (2013). Winner-take-all markets. Studies in Microeconomics, 1(2), 131-154.

Fu, Q., \& Wu, Z. (2019). Contests: Theory and topics. In Oxford Research Encyclopedia of Economics and Finance. 
Anwar Shah, Nasrullah Habib and Muhammad Zeeshan Younas

Goldstein, K., \& Freedman, P. (2000). New evidence for new arguments: Money and advertising in the 1996 Senate elections. The Journal of Politics, 62(4), 10871108.

Green, D. P., \&Krasno, J. S. (1988). Salvation for the spendthrift incumbent: Reestimating the effects of campaign spending in House elections. American Journal of Political Science, 884-907.

Grier, K. B. (1989). On the existence of a political monetary cycle. American Journal of Political Science, 376-389.

Hillman, A. L., \& Katz, E. (1984). Risk-averse rent seekers and the social cost of monopoly power. The Economic Journal, 94(373), 104-110.

Hillman, A. L., \& Riley, J. G. (1989). Politically contestable rents and transfers. Economics \& Politics, 1(1), 17-39.

Jacobson, G. C. (1980). Money in congressional elections. Yale University Press.

Jacobson, G. C. (1985). Money and votes reconsidered: Congressional elections, 19721982. Public choice, 47(1), 7-62.

Jacobson, G. C. (1990). The effects of campaign spending in House elections: New evidence for old arguments. American Journal of Political Science, 334-362.

Johnston, R. J., \& Pattie, C. J. (1995). The impact of spending on party constituency campaigns at recent British general elections. Party Politics, 1(2), 261-273.

Johnston, R. J., \& Pattie, C. J. (1997). Where's the difference? Decomposing the impact of local election campaigns in Great Britain. Electoral Studies, 16(2), 165-174.

Johnston, R. J., Pattie, C. J., \& Allsopp, J. G. (1988). A nation dividing?: the electoral map of Great Britain, 1979-1987. Longman; New York: Wiley.

Krueger, A. O. (1974). The political economy of the rent-seeking society. The American economic review, 64(3), 291-303.

Laband, D. N., \& Sophocleus, J. P. (1988). The social cost of rent-seeking: First estimates. Public Choice, 58(3), 269-275.

Laband, D. N., \& Sophocleus, J. P. (1992). An estimate of resource expenditures on transfer activity in the United States. The Quarterly Journal of Economics, 107(3), 959-983.

Lambsdorff, J. G. (2002). Corruption and rent-seeking. Public choice, 113(1-2), 97-125.

Luchsinger, C., \& Mueller, A. (2003). Incentive Compatible Extraction of Natural Resource Rent. In CEPE Working Paper No. 21, Centre for Energy Policy and Economics (CEPE.

Menon, A. R., \& Yao, D. A. (2017). Rationalizing outcomes: Mental-model-guided learning in competitive markets. Harvard Business School.

Millner, E. L., \& Pratt, M. D. (1989). An experimental investigation of efficient rentseeking. Public Choice, 62(2), 139-151.

112 
Journal of Applied Economics and Business Studies, Volume. 4, Issue 4 (2020) 97-116 https://doi.org/10.34260/jaebs.445

Mbaku, J. M., \& Kimenyi, M. S. (2015). Rents and development failure in Africa. In Companion to the political economy of rent seeking. Edward Elgar Publishing.

Mbaku, J. M. (1994). Military coups as rent-seeking behavior. JPMS: Journal of Political and Military Sociology, 22(2), 241.

Nitzan, S. (1991). Collective rent dissipation. The Economic Journal, 101(409), 15221534.

Nitzan, S. (1994). Modelling rent-seeking contests. European Journal of Political Economy, 10(1), 41-60.

Palda, K. S. (1973). Does advertising influence votes? An analysis of the 1966 and 1970 Quebec elections. Canadian Journal of Political Science/Revue canadienne de science politique, 6(4), 638-655.

Patnaik, S. (2015). Rent-seeking and public policy. Cesifo DICE Report, 13(3), 3-5.

Pattie, C. J., Johnston, R. J., \& Fieldhouse, E. A. (1995).Winning the local vote: the effectiveness of constituency campaign spending in Great Britain, 19831992. American Political Science Review, 89(4), 969-983.

Randall, A. (1983). The problem of market failure. Natural Resources Journal, 23(1), 131-148.

Rovinaru, M., \& Pop, L. (2014). The Subsidies-An Instrument Of Trade Policy. Case Study: The Boeing-Airbus" War". Studies in Business \& Economics, 9(3).

Sagar, P. (2019). The opinion of mankind: sociability and the theory of the state from Hobbes to Smith. Princeton University Press.

Saward, M. (2008). Representation and democracy: revisions and possibilities. Sociology compass, 2(3), 1000-1013.

Sommerville, J. P. (1992). Thomas Hobbes: political ideas in historical context. Macmillan International Higher Education.

Sugden, R. (1991). Rational choice: a survey of contributions from economics and philosophy. The economic journal, 101(407), 751-785.

Sun, J., Schram, A., \& Sloof, R. (2020). Elections under biased candidate endorsements - an experimental study. Games and economic behavior, 125, 141-158.

Tullock, G. (1967). The welfare costs of tariffs, monopolies, and theft. Economic Inquiry, 5(3), 224-232.

Tullock, G. (1971). Subsidized housing in a competitive market: Comment. American Economic Review, 61(1), 218-219.

Tullock, G. (1975). Competing monies. Journal of Money, Credit and Banking, 7(4), 491-497. 
Anwar Shah, Nasrullah Habib and Muhammad Zeeshan Younas

Vriend, N. J. (1996). Rational behavior and economic theory. Journal of Economic Behavior \& Organization, 29(2), 263-285.

Wales case, 1988-95. Environment and Planning A, 31(6), 1119-1128.

Welch, S., \& Hibbing, J. R. (1984). Hispanic representation in the US Congress. Social Science Quarterly, 65(2), 328.

Zupan, M. A. (2015). Rent-Seeking on the Supply Side of Politics. CESifo DICE Report, 13(3), 6-14.

\section{Appendix \\ QUESTIONNAIRE}

Dear Respondent,

We are from the School of Economics Quaid-i-Azam University, Islamabad and working on a research project related to the election campaign. In this regard, we need some information. We shall be grateful if you kindly provide me the following information to the best of your knowledge. We assure you that all information will remain private and used for the purpose of this research. Thanks in advance for your cooperation and valuable time.

Part A: General Profile of the Respondent

Name of the respondent (optional)

Please tick the box next to the answer of your choice.

1). The name of your District is 1 1) Pakpattan 2) Okara

2). The nature of your Union Council is $\quad$ 1) Urban 2) Rural

3). Which seat did you contest for? 1 1) Chairman 2) Vice-chairman

4). Which party ticket did you hold? 1) PTI 2) PMLN3) PPP 4) Independent 5) other (please specify)

5). Which Brothery do you belong to?

6). What is your age?

7). Since how long are you active politically? 1) Since forefathers 2) Since----------Year

8). Did you contest the election before the 2015 local bodies poll? 1) Yes 2) No

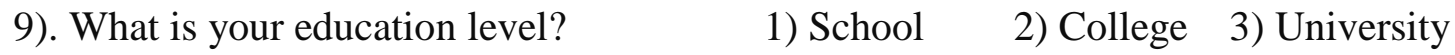

10). Do you have a spiritual relationship with any person/Durbar? 1) Yes $\quad$ 2) No

If yes, then kindly mention the name

11). Did you get any support during the election campaign from your peer? 1) Yes 2) No

Part B: Election Turn Over

12). Total registered voters as per ECP in the constituency

114 
Journal of Applied Economics and Business Studies, Volume. 4, Issue 4 (2020) 97-116 https://doi.org/10.34260/jaebs.445

13). Total casted votes in your constituency

14). How many votes did you receive?

15). Total number of contested candidates

16). Your position in the final outcome of election

17). How many votes did you receive from Brothery?

Part C: Details about Advertisement Cost during the Election Campaign

18). Did you give any advertisement on T.V channels during an election campaign?

1) Yes2) No

If yes, then how much is the approximate total cost of such an advertisement?

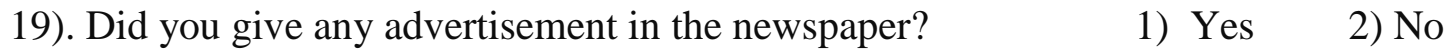

If yes, then how much is the approximate total cost?

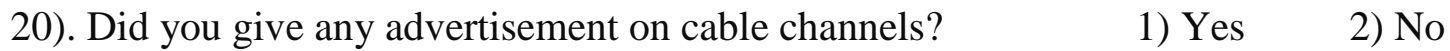

If yes, then how much is the approximate total cost?

21). Can you please tell us that the approximate total cost of Pena flexes (Billboards)?

22). Can you please tell us the approximate total cost of all types of Banners?

23). Can you please tell us the approximate total cost of all types of posters?

24). Can you please tell us the approximate total cost of all types of badges?

25). Can you please tell us the approximate total cost of any kind of flushing types of bill boards?

26). Can you please tell us about the approximate total cost of all types of advertisement including the one we have asked above as well as the one we have not asked for?

Part D: Details about Transportation Cost during the Election Campaign

27). What is the approximate total cost of transportation during the election campaign before the day of the election?

28). What is the approximate total transportation cost on the day of the election?

Part E: Public Meetings during the Election Campaign

29). How many corner meetings did you conduct during an election campaign?

30). What was the approximately average cost of each corner meeting?

31). How many corner meetings were sponsored by other people?

32). How many large public gatherings did you conduct during an election campaign?

33). What was the average cost of each large public gathering?

Part F: Cost on Agents and Other Staff during the Election Campaign

34). Did you hire any staff or agent for the purpose of an election campaign?1) Yes2) No

If yes, how many agents/staff?

$35)$. What is the approximate total cost of an all agent/staff?

Part G: Unsolicited Materials Cost 
Anwar Shah, Nasrullah Habib and Muhammad Zeeshan Younas

36). Can you kindly tell us about the total cost of items other than what we have asked for above?

37). Did anyone ask (demand) for financial help before the election? 1) Yes 2)No If yes, then how much help did you make?

Part H: Cost on the Day of Election at Each Polling Station

38). How many polling stations are in your union council?

39). How much is the average cost of each polling station on the day of the election?

Part I: Personal Expenses during the Election Campaign

40). Did you buy or hire any special vehicle during an election campaign? 1) Yes 2)No If yes, then how much is the total cost?

41). Did you hire a special gunman for security purposes during an election campaign?

1) Yes 2) No if yes, then how much is the total cost?

42). Did you buy any weapon for security purposes during an election campaign?

1)Yes 2)No If yes, then how much is the total cost?

43). Did you do any personal shopping during an election campaign? 1) Yes 2 2) No If yes, then how much is the total cost?

44). Any other expense which we did not ask in the above question?

45). Did you become the chief guest in any type of sports tournament during the election campaign?

1) Yes 2) No If yes then, how many times?

46). Did you announce any prize or sponsorship in the capacity of chief guest?

1) Yes 2) No If yes then, how much?

Part J: Donations

47). Did you receive any donations? 1 1) Yes 2) No If yes, then how much?

48). Did you reject any offer of donation? 1) Yes 2) No

If yes, then how much?

Part K: Source of Livelihood

49). What is the nature of your Job 1 1) lawyer $\quad$ 2) Businessman 3 3) Zamindari 4)

Other

50). Did you inherit any assets from your forefathers? 1 1) Yes $\quad$ 2) No

If yes then, how much? 